Article

\title{
The effectiveness of baby massage in increasing infant's body weight
}

\author{
Kurniati Puji Lestari, ${ }^{1}$ Firdha Rahma Nurbadlina, ${ }^{1}$ Wagiyo ${ }^{1}$, Muhamad Jauhar ${ }^{2}$ \\ ${ }^{1}$ Nursing Department, Health Polytechnic of Ministry of Health Semarang, Semarang, Central Java; ${ }^{2}$ Nursing \\ Department, Faculty of Health Sciences, Universitas Muhammadiyah Kudus, Kudus, Central Java, Indonesia
}

\begin{abstract}
Background: The low birth weight (LBW) problem is found in various developing countries with an increasing trend of cases every year. This is caused by nutritional status and a history of maternal health. The impact of LBW in children is they are more likely to experience delayed growth and development. This study aims to identify the effect of baby massage on infants' body weight.

Design and Methods: The research design used was quasiexperimental pre and post-test type with control group. There were 16 infants for each group selected by purposive sampling. Baby massage was given to the infants twice a week within four weeks, 10 to 15 mins per session. Data analysis was used paired $t$ test and independent $t$-test.

Results: The mean age of infants was 3.69 months for both group, the mean age at birth was 37.8 weeks (intervention) and 38 weeks (control), the mean birth weight of infants was 2,295 grams (intervention) and 2,288 grams (control). Most of the infants was male for both group. There was an effect of baby massage on the increase in infants' weight gain with a history of low birth weight significantly with a p-value $<0.05$.

Conclusions: Baby massage can increase infants' weight with a history of low birth weight aged 1-6 months. The role of health workers is to provide education and practice baby massage for mothers in order to stimulate the growth and development of infants. This intervention can be integrated with maternal and child health programs in primary health care facilities.
\end{abstract}

\section{Introduction}

Low birth weight (LBW) is a condition in which babies are born weighing less than 2500 grams. ${ }^{1}$ According to the World Health Organization, in 2018 the incidence of low birth weight in the world reached $15.5 \% .90 \%$ of these cases occur in developing countries including Indonesia. In another word, there are 1 in 7 babies born with low birth weight in the world. ${ }^{2}$ Indonesia is ranked ninth in the world with cases of LBW infants reaching $15.5 \%{ }^{3}$ Based on the basic health research data from the Ministry of Health of the Republic of Indonesia, LBW cases in Central Java were $6.2 \%$, equivalent to the average number of LBW cases in
Indonesia. In particular, LBW cases in 2018 in Semarang City were 506 cases $(2.02 \%){ }^{4}$

The occurrence of LBW is influenced by three factors, namely factors of mother, baby, and placenta. Maternal factors play a very large role in the incidence of LBW. As much as $65 \%$ is influenced by the mother's educational background, maternal age at pregnancy, the distance between previous and current pregnancies, the number of frequencies of antenatal care, the presence of chronic diseases. Inadequate nutritional intake and a very dense mother's activity can trigger stress so that it affects the incidence of low birth weight. History of mothers who gave birth to premature babies at risk of preterm delivery in subsequent pregnancies. ${ }^{5}$ Women who become pregnant at the age of less than 20 years, the risk of prematurity is very high. Another factor that affects is the geographical conditions of the area, socio-economy, and culture.

LBW babies have a higher risk of morbidity and mortality during the neonatal period than babies of normal weight. Babies born with a body weight of 2000-2500 grams are more likely to experience neonatal mortality four times greater than babies weighing 2500-3000 grams, and are ten times more susceptible to disease than babies born weighing 3000-3500 grams. ${ }^{6}$ Exclusive breastfeeding is needed for LBW babies during the stages of growth and development. Breast milk is one of the best foods for babies because it contains nutritional elements needed by babies which are useful for supporting optimal growth and development. ${ }^{4}$

The government's effort to prevent cases of LBW is the existence of the One thousand First Day of Life (1000 HPK) program with the provision of supplementary food to pregnant women. Provision of milk and iron tablets can prevent anaemia for pregnant women and provide health education to mothers and their families. Mothers are also encouraged to do routine pregnancy checks through monthly antenatal care service. The government collaborates with midwives in villages to extend the effort. One of the interventions that can be given to LBW babies in stimulating growth and development is baby massage.

Baby massage is a tactile stimulation that can stimulate muscles, bones and organ systems so that they can function optimally. ${ }^{7}$ According to Health and Bainbridge, baby massage will stimulate the vagus nerve. This nerve will increase the working capacity of the intestinal peristaltic so that gastric emptying will be faster and the baby will feel hungry easily. ${ }^{8}$ In addition, baby massage can also improve blood circulation and increase the body's metabolism, thereby increasing the baby's weight. Baby

Significance for public health

The capacity of countries to develop, grow, and compete, depends on a healthy and productive population. Children are the basis of all dimensions of sustainable development. Approximately 7 million children die each year before their fifth birthday. In less developed countries, over 200 million children who make it to life cannot achieve the proper development stages. Health workers are the backbone to the community, especially to mothers, in terms of assuring the quality of public health. Therefore, this research aims to familiarize the effectiveness of baby massage in improving babies with condition of low birth weight. The massage is proven to help the process of child's growth and development. 
massage is an expression of affection between parents and children through skin touch. ${ }^{7}$ The benefits of baby massage include increasing body weight and growth, increasing endurance, increasing baby concentration and making babies sleep soundly, fostering bonds of affection for parents and children, ${ }^{8}$ increasing milk production. Infant massage can also have negative effects if done inappropriately such as trauma or bruising to the skin and muscles, pain in the baby so that the baby becomes fussy, muscle and bone injuries, and swelling. As long as baby massage is done properly and gently, baby massage is safe, even beneficial. ${ }^{9}$ To further investigate the advantage of infant massage, this study conducts a series of demonstrations and examinations on LBW infants at the age of 1-6 months in several government-owned primary health care facilities in Semarang City.

\section{Design and Methods}

The research design used was a quasi-experiment pre-test and post-test with control group type. This research was conducted in January-February 2020 in three government-owned primary health care facilities in Semarang City. The study population was 32 babies with a history of LBW aged 1-6 months in the working area of primary health care facilities. The number of research samples was 16 respondents for each intervention and control group. The sampling technique used is total sampling. Inclusion criteria for infants with a birth history of LBW, age 1-6 months, exclusive breastfeeding, maternal BMI within the normal range. Exclusion criteria including infants who were sick, had genetic disorders, had received complementary foods with breast milk. The independent variable is baby massage and the dependent variable is infants' weight. The intervention given was to massage the baby for 10-15 mins twice a week for four weeks in the afternoon before the infants' showered. The research instrument used was a weight observation sheet, a calibrated GEA medical Rgz 20A manual baby weight scale. An explanation of the research information and informed consent was provided before data collection started. Researchers measured the infants' weight before, during, and after being given baby massage. Univariate analysis was described in terms of frequencies and percentages for gender characteristics. Data for infants' age, gestational age at birth, and birth weight are presented as mean and standard deviation. Bivariate analysis was conducted using independent dan dependent $t$-test. Data analysis using computer-based statistical program software. This study had obtained the ethical approval from the Health Research Ethics Committee of the Health Polytechnic of Ministry of Health Semarang No.007/EA/KEPK/ 2020.

\section{Results}

As illustrated in Table 1, the mean age of infants in the intervention and control groups was 3.69 months. The mean age at birth at birth in the intervention group was 37.8 weeks and the control group was 38 weeks. The mean birth weight of infants in the intervention group was 2.295.12 grams and the control group was 2.288.75 grams. Based on Table 2, Most of the babies in the intervention group were male, as many as 9 infants $(56.2 \%)$ and half of the respondents in the control group were male, as many as 8 infants $(50 \%)$. Based on Table 3, the mean weight of infants before

Table 1. Characteristics of infants based on age, maternal age at birth, and birth weight $(n=32)$.

\begin{tabular}{|c|c|c|c|c|c|c|c|}
\hline Classification & Number of respondents & Min & $\operatorname{Max}$ & Mean & Median & Std. deviation & SE \\
\hline \multicolumn{8}{|c|}{ Age of infants (in months) } \\
\hline Intervention & 16 & 2 & 5 & 3.69 & 4.00 & 0.946 & 0.237 \\
\hline Control & 16 & 2 & 5 & 3.69 & 4.00 & 1.078 & 0.270 \\
\hline \multicolumn{8}{|c|}{ Age of pregnancy at birth (in weeks) } \\
\hline Intervention & 16 & 35 & 38 & 37.8 & 36,50 & 1.094 & 0.273 \\
\hline Control & 16 & 35 & 39 & 38 & 37.00 & 1.155 & 0.286 \\
\hline \multicolumn{8}{|c|}{ Infants' birth weight (in grams) } \\
\hline Intervention & 16 & 2100 & 2450 & 2295.12 & 2300 & 113.55 & 28.389 \\
\hline Control & 16 & 2000 & 2450 & 2288.75 & 2300 & 133.56 & 33.390 \\
\hline
\end{tabular}

Table 2. Infant characteristics based on sex $(n=32)$.

\begin{tabular}{|c|c|c|c|c|c|}
\hline \multirow[t]{2}{*}{ Gender } & \multirow[t]{2}{*}{ Total } & \multicolumn{2}{|c|}{ f } & \multicolumn{2}{|c|}{$\%$} \\
\hline & & Male & Female & Male & Female \\
\hline Intervention & 16 & 9 & 7 & 56.2 & 43.8 \\
\hline Control & 16 & 8 & 8 & 50.0 & 50.0 \\
\hline
\end{tabular}

Table 3. Description of infants' weight (in grams) before and after the intervention.

\begin{tabular}{lccccc} 
Data & Mean & Difference in mean & Median & Std. deviation & Min \\
Intervention & & & & & \\
BW before & 5356.25 & 500.00 & 5050.00 & 965.38 & 3900 \\
BW after & 5856.25 & & 5750.00 & 1075.15 & 4200 \\
Control & & & & & \\
BW before & 5287.50 & 268.75 & 5500.00 & 840.53 & 4000 \\
BW after & 5556.25 & & 5850.00 & 840.61 & 4300 \\
\hline
\end{tabular}


intervention in the intervention group amounted to 5,356.25 grams and in the control group 5,287.50 grams. The mean weight of infants after the intervention in the intervention group was 5.856.25 grams and in the control group was 5.556.25 grams. The difference in the mean weight of infants before and after the intervention in the intervention group was 500 grams and in the control group was 268.75 grams. According to Table 4, it was found that there was a significant increase on infants' weight after receiving baby massage $(\mathrm{p}=0.001)$.

\section{Discussion}

The results shows that infants' ages ranged from 1-6 months, so they are included in the age category of mandatory exclusive breastfeeding. ${ }^{4}$ Exclusive breastfeeding is very important in the growing period of the baby because the first 1000 days of life determine the growth and development status of an individual when he is an adult. Infants have certain characteristics at every stage of their age. The average of infants' weight gain per month based on age is 1000 grams.

Based on the age of the womb at birth, it was found that the average age of infants at birth was 37 weeks. The age of the womb greatly affects the condition of the baby to be born. Based on the age of the womb when the baby is born, babies are categorized as preterm babies ( $<37$ weeks) with weight according to their gestation period or commonly called preterm neonates according to gestational period (NBK-SMK) and immaturity, the weight of the baby is born less than supposed to be for her gestation. Babies are growth retarded and babies are small for their pregnancy (KMK). These two things are caused by the inability of the uterus to hold the fetus, disturbances during pregnancy, the release of the placenta earlier than the time, or stimulation that facilitates uterine contractions before term. ${ }^{10}$

Based on research, the average birth weight of babies is 2300 grams. Body weight is used to determine a normal baby or LBW. LBW babies if the weight of the infants, the birth weight of the baby is below 2500 grams. Based on previous research, there was a significant increase in body weight which was applied to 20 infants aged 0-3 months with a normal body weight of at least 2700 grams and a maximum body weight of 3300 grams with an average of 2,975 grams. After the baby massage, the baby's weight increased significantly by an average of 3175 grams, minimum body weight of 2.850 grams, maximum body weight of 3,400 grams. The increase in average body weight that occurs is 200 grams after baby massage twice a week for 2 weeks. ${ }^{11}$

The results showed that there was a difference in weight gain before and after the intervention in the intervention group, namely 500 grams. Whereas in the control group there was a smaller difference in weight gain before and after, namely 268.75 grams. In addition, it also shows that baby massage has a significant effect on increasing the baby's weight statistically. This difference in body weight is in accordance with the theory presented by Sowden that babies will gain weight of approximately 500 grams per week when the baby is 1 month old. ${ }^{12}$ In Astriana and Suryani's research on the effect of infant massage, the group that received the infant massage stimulation intervention showed a feeling of calm during sleep, not often waking up at night and when awakened would immediately suckle strongly for a longer time. The baby's ability to breastfeed that is stronger and longer will certainly affect the nutritional adequacy of LBW which will certainly have an impact on weight gain. ${ }^{13}$

The factors that affect infant growth include stimulation. The
Table 4. Effect of baby massage on infants' weight (in grams).

\begin{tabular}{lccc}
\hline Infants' weight & n & Mean & p-value \\
Intervention group & 16 & 500.00 & 0.001 \\
Control group & 16 & 268.75 & 0.001 \\
\hline
\end{tabular}

stimulation referred to in this study is the provision of infant massage. Infants who are massaged are not hungry (already breastfed 1 hour before the massage) will provide maximum results. Massage on infants will increase the baby's growth. When tactile stimulation is carried out, there will be an increase in the ornithine decarboxylase enzyme, which is an enzyme that guides cell and tissue growth.

Infant massage can increase the absorption of food because the baby who is massaged will experience an increase in the tone of the vagus nerve ( $10^{\text {th }}$ brain nerve) which will cause an increase in levels of the enzyme absorption of gastrin and insulin. Baby massage is a tactile stimulation that can stimulate muscles, bones and organ systems so that they can function optimally. ${ }^{7}$ According to Health and Bainbridge, baby massage will stimulate the vagus nerve. These nerves will increase the work of the intestinal peristaltic so that the emptying of the stomach will be faster and the baby will feel hungry easily. ${ }^{8}$ Infant massage provides many benefits for babies and parents, both psychologically and baby development. Touch is the first language of parents and children that can strengthen the bonds of affection between them. Infant massage is an expression of affection between parents and children through the touch of the skin which has an extraordinary impact. ${ }^{7}$

Baby massage can increase beta endorphins, which affect the growth mechanism, besides that it also increases the tone of the vagus nerves which affects the absorption mechanism of breast milk so that the baby will quickly hungry and breastfeeding more frequently on the mother, which also results in increased milk production. The effect of increasing body weight was also found in babies born at term. A study in China proves that there is an effect of infant massage for 10-15 mins a day since the baby was 15 days old. At 2 months of age, babies who were routinely massaged showed a difference in body weight compared to babies who were not massaged. In infants who were routinely massaged, the average weight gain for one month was 900 grams. Whereas in infants who were not given massage the average body weight for one month was 760 grams. ${ }^{14}$

Supported by the results of Sunarsih's research, it was explained that there were differences in body weight in the two groups of infants studied. ${ }^{11,15}$ Massages on babies will increase serotonin neurotransmitter activity, which increases the capacity of receptor cells that bind glucocorticoid (adrenaline, a stress hormone), resulting in a decrease in adrenal hormone (a stress hormone), a decrease in levels of this stress hormone will increase endurance. Massage on babies will stimulate the vagus nerve, where this nerve will increase intestinal peristalsis to empty the stomach, so the baby is hungry quickly, so food intake will increase. ${ }^{16} \mathrm{~A}$ research concluded that there was a significant difference in weight gain between term babies who were given massage stimulation, compared with babies who did not receive massage, the difference in the average body weight of babies who were massaged and did not reach 440 grams. ${ }^{17}$ The massage is performed on newborn for 15 minutes a day at home for a period of 4 weeks. The difference in weight gain was seen at 4 weeks of age. The effect of massage on growth is evidenced by research which shows that after regular infant massage is done every 2 times in 1 week for 4 weeks by the parents of each baby, the results show that most babies experience 
an increase in body weight of more than 1000. gram which was done on 11 babies, evidenced by the results of the p-value before $=0.454$ and the $\mathrm{p}$-value after $=0.121 .{ }^{11}$ Based on the results of the paired $t$-test, it was found that $\mathrm{p}$-value $=0.000$, because the $\mathrm{p}$ value $<\alpha=0.05$. Comparison of the mean value of body weight before infant massage was 2975 grams, and an increase in the mean value after infant massage was 3175 grams. Based on the results of the p-value and the average comparison between body weight before and after, the conclusion is that infant massage is proven to be effective in increasing baby weight.

The results of baby massage weight that changed after intervention were in accordance with the theory put forward by Astriana and Suryani about stimulation of growth and development in children, ${ }^{13}$ strengthened by a Küpers et al.'s research with $p$-value $=0.011$ states the effect of massage and weight gain for infants, especially babies born prematurely. ${ }^{18}$ Massage increases the body's vagal activity (neural activity), thereby triggering the release of hormones that play a role in food absorption, such as gastrin and insulin, and indirectly increasing the baby's appetite and weight. Another theory states that massage the whole body can improve blood circulation and lymph nodes, including the digestive tract. This helps to smooth the digestive system and can help the absorption of nutrients by the tissue. Most of these effects occur in babies born prematurely. ${ }^{13}$

Baby massage has many benefits for babies, namely increasing baby weight, growth, immunity, concentration, and making them sleep more soundly and strengthen the bond of affection between parent and child. In good health and well-nourished, the baby's body weight in the first year of life has increased by 140-200 grams per week. The results showed that 15 babies who were not given massage experienced changes in body weight by an average of $1.42 \%$, with the paired sample $t$-test obtained $\mathrm{p}=0.005$. The 15 babies who were given massage also experienced an increase in body weight of $4.11 \%$, with the paired sample $t$-test obtained $p=0.000$. On the other hand, in the comparison of weight gain between infants who did not receive massage and babies who received massage, the results of the free sample $t$-test were $p=0.001$. The conclusion of this study is the effect of infant massage on the increase in body weight of infants aged 0-6 months. Based on several research results, it was found that baby massage can increase baby weight during growth and development. Infant massage is one of the interventions that nurses can do independently. Modification of independent nursing action needs to be done so that the capacity of nurses as providers of nursing and health services can be taken into account. The public will be confident in the nurse's capacity in providing non-pharmacological therapy according to client needs. It is necessary to develop nursing interventions so that they can trigger the scientific development of nursing as a professional profession. Nurses in this case act as educators, namely providing health education to mothers about infant massage, care givers, namely direct infant massage, researchers, namely developing independent nursing interventions that can solve client health problems, and collaborators, namely collaborating with mothers and families in providing care best for the baby so that the baby's future is guaranteed.

The results showed that there was an effect of baby massage on the significant increase in infants' weight. Baby massage as a form of stimulus to the baby and increasing the bond between mother and child can stimulate the growth and development of the baby. The future of the baby depends on the health status of the baby in the first 100 days of birth, so the nurse and family must be able to ensure that the growth and development process can be passed optimally. Infant massage interventions can be integrated with maternal and child health programs in health care facilities through family empowerment. It is necessary to have standard operating procedures so as to minimize errors in applying baby massage. Various forms of media can be developed such as booklets, modules, manuals, posters, and interactive videos to support the process of giving baby massage interventions. The results of this study can also be used as a basis for identifying other forms of intervention that are more effective in increasing baby weight. Besides that, it can also be used as a consideration in determining other variables that can be increased through infant massage such as body length, height, nutritional status, sleep quality, and so on.

Correspondence: Kurniati Puji Lestari, Nursing Department, Semarang Health Polytechnic, Jalan Tirto Agung, Semarang 56024, Central Java, Indonesia.

Tel. +624.7470364 - Fax: +624.7470364 .

E-mail: pujilestarikurniati@gmail.com

Key words: Infant; low birth weight; massage; weight gain.

Contributions: KPL, FRN, W, MJ, proposed the idea and planned the research;KPL, FRN, MJ, contributed to write the manuscript. All authors were joined hands to implement, analyse, discuss, and conclude the data. All the authors committed an equal contribution to the research. All the authors have read and approved the final version of the manuscript and agreed to be accountable for all aspects of the work.

Conflict of interest: The authors declare that they have no competing interests, and all authors confirm accuracy.

Acknowledgments: Many thanks to Nursing Department Health Polytechnic of Ministry of Health Semarang, Semarang City Health Office, Padangsari, Pudakpayung and Srondol Primary Health Care Services for valuable supports.

Institutions where the research was carried out: Three government-owned primary health care facilities in Semarang City, Indonesia.

Ethics Approval: This study had obtained the ethical approval from the Health Research Ethics Committee of the Health Polytechnic of Ministry of Health Semarang No.007/EA/KEPK/2020.

Availability of data and materials: The data used to support the findings of this study are available from the corresponding author on reasonable request.

Conference presentation: This final manuscript has been presented at $7^{\text {th }}$ Virtual Biennial International Nursing Conference, Faculty of Nursing, Universitas Indonesia on September $24^{\text {th }}$, October $30^{\text {th }}$, November $16^{\text {th }} 2020$.

Received for publication: 20 August 2020.

Accepted for publication: 1 February 2021.

oCopyright: the Author(s), 2021

Licensee PAGEPress, Italy

Journal of Public Health Research 2021; 10(s1):2332

doi:10.4081/jphr.2021.2332

This work is licensed under a Creative Commons Attribution NonCommercial 4.0 License (CC BY-NC 4.0).

\section{References}

1. Hartiningrum I, Fitriyah N. [Bayi berat lahir rendah (BBLR) di Provinsi Jawa Timur tahun 2012-2016 (Low birth weight 
babies (LBW) in East Java Province 2012-2016)].[Article in Indonesian. Jurnal Biometrika dan Kependudukan 2018;7:97104.

2. Bracho-Sanchez E. 1 in 7 babies is born underweight with dire consequences for their health [Internet]. Hong Kong: Cable News Network International. Accessed: 2019 Nov 29. Available

from https://edition.cnn.com/2019/05/15/health/underweight-newborns-global-study/index.html

3. Ika. [Jumlah bayi berat lahir rendah masih tinggi (The number of low birth weight babies is still high)].[In Indonesian]. Yogyakarta: Universitas Gadjah Mada. Available from: https://ugm.ac.id/id/berita/10695-jumlah-bayi-berat-lahir-rendah-masih-tinggi

4. Semarang City Health Office. [Profil kesehatan Kota Semarang tahun 2018 (Semarang City health profile in 2018)].[In Indonesian]. Accessed: 2019 Nov 29. Available from: https://dinkes.semarangkota.go.id/asset/upload/Profil/ Profil\%20Kesehatan\%202018.pdf

5. Hidayati I. [Faktor-faktor yang mempengaruhi kejadian berat badan lahir rendah (Factors affecting the incidence of low birth weight)].[Thesis in Indonesian]. Yogyakarta: Universitas 'Aisyiyah Yogyakarta; 2016.

6. Putra WKY. [Pengukuran antropometri pengganti untuk mendeteksi kasus BBLR di Kota Pontianak dan Kabupaten Kubu Raya tahun 2011 (Replacement anthropometric measurements to detect LBW cases in Pontianak City and Kubu Raya Regency in 2011)].[Thesis in Indonesian]. Depok: Universitas Indonesia; 2012.

7. Griya Husada Midwifery Academy [Internet]. [Modul pijat bayi (Baby massage module)].[In Indonesian]. Surabaya: Akademi Kebidanan Griya Husada. Available from: https:/griyahusada.id/files/modul/MODUL_PIJAT_BAYI.pdf

8. Lorenz L, Moyse K, Surguy H. The benefits of baby massage. Paediatr Nurs 2005;17:15-8.

9. Gürol R, Polat S. The effects of baby massage on attachment between mother and their infants. Asian Nurs Res (Korean Soc Nurs Sci) 2012;6:35-41.

10. Yanti L, Surtiningsih. [Faktor karakteristik ibu terhadap berat bayi lahir rendah (Maternal characteristic factors for low birth weight)].[Article in Indonesian]. In: Fathurohman A, editor. roceedings of Contribution of Research Results and Community Service in the Sustainable Development Goals (SDGs) Program. RAKERNAS AIPKEMA 2016: National Scientific Meeting of Research and Community Service Results, Semarang, Indonesia. Semarang: Institute for Research and Community Service, University of Muhammadiyah Semarang; 2016. p. 210-4.

11. Mutmainah M, Hartini S, Solechan A. [Efektivitas pijat bayi terhadap berat badan bayi usia 0-3 bulan di SMC RS Telogorejo (The effectiveness of baby massage on body weight of infants aged 0-3 months at SMC Telogorejo Hospital)].[Article in Indonesian]. Jurnal Ilmu Keperawatan dan Kebidanan 2016;8:178-87.

12. Betz CL, Sowden LA. [Buku saku: keperawatan pediatri (Pocket book: pediatric nursing)].[Book in Indonesian]. 5th ed. Jakarta: EGC; 2009.

13. Astriana, Suryani IL. [Pengaruh Pijat bayi terhadap peningkatan berat badan pada bayi di BPS Masnoni Teluk Betung Utara Kota Bandar Lampung (Effect of infant massage on weight gain in infants at BPS Masnoni Teluk Betung Utara Kota Bandar Lampung)].[Article in Indonesian].Holistik Jurnal Kesehatan 2017;11:72-6.

14. Lee HK. The effect of infant massage on weight, height, and mother infant interaction. Taehan Kanho Hakhoe Chi 2006;36:1331-9.

15. Rosyida A. [Pengaruh pijat bayi terhadap kenaikan berat badan bayi umur 0-3 bulan di BPS Saraswati Sleman Yogyakarta tahun 2010 (The effect of baby massage on weight gain for babies aged 0-3 months at BPS Saraswati Sleman Yogyakarta in 2010)].[Thesis in Indonesian]. Yogyakarta: General Ahmad Yan College of Health Sciences; 2010.

16. Gonzalez AP, Vasquez-Mendoza G, García-Vela A, et al. Weight gain in preterm infants following parent-administered vimala massage: a randomized controlled trial. Am J Perinatol 2009;26:247-52.

17. Dewi VNL. [Asuhan neonatus bayi dan anak balita (The care of neonates for infants and children under five)].[Book in Indonesian]. Jakarta: Salemba Medika; 2011.

18. Küpers LK, Abée CL, Bocca G, et al.Determinants of weight gain during the first two years of life - The GECKO Drenthe birth cohort. PLoS One 2015;10:e133326. 